Relations industrielles

Industrial Relations

\title{
Index - Volume 65 - 2010
}

Volume 65, numéro 4, 2010

URI : https://id.erudit.org/iderudit/045601ar

DOI : https://doi.org/10.7202/045601ar

Aller au sommaire du numéro

Éditeur(s)

Département des relations industrielles de l'Université Laval

ISSN

0034-379X (imprimé)

1703-8138 (numérique)

Découvrir la revue

Citer ce document

(2010). Index - Volume 65 - 2010. Relations industrielles / Industrial Relations, 65(4), 698-702. https://doi.org/10.7202/045601ar

Tous droits réservés (C Département des relations industrielles de l'Université Laval, 2010
Ce document est protégé par la loi sur le droit d'auteur. L’utilisation des services d'Érudit (y compris la reproduction) est assujettie à sa politique d'utilisation que vous pouvez consulter en ligne.

https://apropos.erudit.org/fr/usagers/politique-dutilisation/ 


\section{Index - Volume $65-2010$}

\section{ARTICLES}

\section{Volume 65-1}

Trade Unions and "Europe": Are the Members Out of Step?

RICHARD HYMAN

Tendencias actuales de la afiliación sindical en Argentina: evidencias de una

encuesta a empresas.

CECILIA SENÉN GONZÁLEZ, DAVID TRAJTEMBERG Y BÁRBARA MEDWID

Les transformations socioprofessionnelles de l'encadrement de premier niveau :

une comparaison France-Québec.

ANNE GILLET

Gender Differences in Precarious Work Settings

MARISA C. YOUNG

Beyond Work-Family Balance: Are Family-Friendly Organizations More Attractive? ANNE BOURHIS AND REDOUANE MEKKAOUI

In Good Faith? An Analysis of the Features and Outcomes of Duty of Fair Representation Cases.

FIONA A. E. MCQUARRIE

Mondialisation et action collective patronale : deux réalités conciliables ? 134 MÉLANIE LAROCHE

\section{Volume 65-2}

Employer Offered Family Support Programs, Gender and Voluntary and Involuntary Part-Time Work.

ISIK U. ZEYTINOGLU, GORDON B. COOKE AND SARA L. MANN

Penser le renouveau syndical par la sphère financière

URWANA COIQUAUD ET LUCIE MORISSETTE

Industrial Voluntarism in Canada.

SEAN TUCKER AND ALEX MUCALOV

Toward a Career Anchor Structure: An Empiricial Investigation of Engineers

LAURA WILS, THIERRY WILS AND MICHEL TREMBLAY

Les logiques d'action collective d'associations regroupant des travailleurs

indépendants

MARTINE D'AMOURS

Progress on Women's Equality within UK and Canadian Trade Unions:

Do Women's Structures Make a Difference?

JANE PARKER AND JANICE FOLEY

Effectiveness of Canada's Employment Equity Legislation for Women

(1997-2004): Implications for Policy Makers 


\section{Volume 65-3}

La coordination patronale face à l'ouverture des marchés : I'industrie suisse des machines depuis les années 1990

FRÉDÉRIC WIDMER

The Regulation of Paid Care Workers' Wages and Conditions in the Non-Profit Sector:

A Toronto Case Study.

SARA CHARLESWORTH

Le maintien dans l'emploi des travailleurs âgés dans trois entreprises belges. 400

FRANÇOISE BERTRAND, CÉCILE LEMAIRE, MARIE BARBIER ET ISABELLE HANSEZ

Employment Relations in Chile: Evidence of HRM Practices

JENNY K. RODRÍGUEZ

La formation en organisation : mise en perspective des approches

psychosociologiques et ergonomiques.

DANIEL FAULX ET LUCIE PETIT

Pay Satisfaction, Job Satisfaction and Turnover Intent.

PARBUDYAL SINGH AND NATASHA LONCAR

Une analyse longitudinale (1975-2005) de l'évolution de la profession

ressources humaines

VICTOR Y. HAINES III, SOPHIE BROUILLARD ET NATHALIE CADIEUX

\section{Volume 65-4}

What Do Unions Do to Innovation? An Empirical Examination of the Canadian

Private Sector

SCOTT WALSWORTH

Intégration socioprofessionnelle des immigrants récents au Québec :

le rôle de l'information et des réseaux sociaux.

KAMEL BÉJI ET ANAÏS PELLERIN

Career Satisfaction: A Look behind the Races

MARGARET YAP, WENDY CUKIER, MARK ROBERT HOLMES AND CHARITY-ANN HANNAN

Analyse de la relation entre les dispositions personnelles

et le conflit travail-famille.

SYLVIE ST-ONGE, GUYLAINE DESCHÊNES ET STÉPHANE RENAUD

A New Approach to Regulating Temporary Agency Work in Ontario

or Back to the Future?

LEAH F. VOSKO

L'expérience de travail en centre d'appels : aux confins de l'engagement

et de la distanciation.

GILLES MARCOUX

\section{NOTE CRITIQUE / REVIEW ESSAY}

Human Rights and the Workplace in a Global Market Economy 


\section{RECENSIONS / BOOK REVIEWS}

\section{Volume 65-1}

Travail et genre : regards croisés France, Europe, Amérique latine

Sous la direction de Helena Hirata, Maria Rosa Lombardi et Margaret Maruani

CATHERINE LE CAPITAINE

The Dirty Work of Neoliberalism: Cleaners in the Global Economy.

Edited by Luis L.M. Aguiar and Andrew Herod

TRAVIS WILLIAM FAST

Les nouveaux cadres du dialogue social : Europe et territoires.

Sous la direction de Annette Jobert

FRÉDÉRIC HANIN

Why David Sometimes Wins: Leadership, Organization, and Strategy

in the California Farm Worker Movement.

By Marshall Ganz

SHELDON KEITH

L'argent noir des syndicats

Par Roger Lenglet, Jean-Luc Touly et Christophe Mongermont

MONA-JOSÉE GAGNON

No Small Change: Pension Funds and Corporate Engagement

By Tessa Hebb

OLGA ARTEMOVA

Donner et prendre : la coopération en entreprise 164

Par Norbert Alter

MIRCEA VULTUR

\section{Volume 65-2}

International and Comparative Labour Law: Current Challenges

By Arturo Bronstein

PIERRE VERGE

Immigration and Integration in Canada in the Twenty-first Century

Edited by John Biles, Meyer Burstein and James Frideres

MICHEL RACINE

The Effects of Mass Immigration on Canadian Living Standards and Society.

Edited by Herbert Grubel

OLGA ARTEMOVA

Sociologie des relations professionnelles.

Par Michel Lallement

Sociologie du travail : les relations professionnelles

Par Antoine Bevort et Annette Jobert

REYNALD BOURQUE 
The Human Side of Outsourcing: Psychological Theory

and Management Practice

Edited by Stephanie Morgan

ROBIN PRICE

Getting the Goods: Ports, Labor, and the Logistics Revolution

Edited by Edna Bonacich and Jake B. Wilson

JEAN SEXTON

Handbook of Work-Family Integration: Research, Theory and Best Practices

Edited by Karen Korabik, Donna S. Lero and Denise L. Whitehead

DIANE-GABRIELLE TREMBLAY

The European Sectoral Social Dialogue: Actors, Developments and Challenges

Edited by Anne Dufresne, Christophe Degryse and Philippe Pochet

DAVID MANGAN

\section{Volume 65-3}

Interrogating the New Economy: Restructuring Work in the $21^{\text {st }}$ Century

Edited by Norene J. Pupo and Mark P. Thomas

BOB RUSSELL

The Transformation of Labour Law in Europe : A Comparative Study

of 15 Countries, 1945-2004

Sous la direction de Bob Heppel et Bruno Veneziani

PIERRE VERGE

La précarité : une relation entre travail, organisation et santé

Coordonné par Gilbert de Terssac, Corinne Saint-Martin et Claire Thébault

MARTINE D'AMOURS

Hired Hands or Human Resources? Case Studies of HRM Programs

and Practices in Early American Industry

By Bruce E. Kaufman

ANTHONY M. GOULD

Le Japon au travail

Par Bernard Bernier, avec la collaboration de Vincent Mirza

ÉTIENNE CANTIN

La construction sociale des acteurs de l'entreprise

Par Marc Maurice

SID AHMED SOUSSI

Worker Representation and Workplace Health and Safety..

By David Walters and Theo Nichols

GENEVIÈVE BARIL-GINGRAS

Labour Conditions for Construction: Building Cities, Decent Work

and the Role of Local Authorities

Edited by Roderick Lawrence and Edmundo Werna

BRADLEY BOWDEN 


\section{Volume 65-4}

Les droits fondamentaux au travail : origines, statut et impact en droit international. 680

Par Claire La Hovary

P. MARTIN DUMAS

Où va la protection sociale?

Sous la direction de Anne-Marie Guillemard

HEDVA SARFATI

Globalization, Flexibilization and Working Conditions in Asia and the Pacific.

Edited by Sangheon Lee and François Eyraud

OLGA ARTEMOVA

Understanding Labour and Employment Law in China

By Ronald C. Brown

MATHIEU DUPUIS

Gender and the Contours of Precarious Employment

Sous la direction de Leah F. Vosko, Martha MacDonald et lain Campbell

SAMIR AMINE

Organisation pathogène du travail et maintien durable en emploi :

une question antinomique?

Sous la direction de Marie-France Maranda et Geneviève Fournier

MARIE BELLEMARE 